Int. J. Dev. Biol. 53: 1253-1259 (2009)

doi: $10.1387 / \mathrm{ijdb} .072278 \mathrm{md}$

\title{
A personal account of the development of modern biological research in Portugal
}

\author{
MARIA DE SOUSA* \\ Instituto de Biologia Molecular e Celular (IBMC), Instituto de Ciências Biomédicas Abel Salazar (ICBAS), Porto, Portugal
}

\begin{abstract}
Portugal celebrated in $\mathbf{2 0 0 6}$ its first 20 years of the formal introduction of the practice of external evaluation of research proposals in the national funding system. Accounts of changes in numbers of publications, citations, numbers of research projects funded and budget figures can be found in Government Reports (www.oces.mctes.pt.). An offshoot of the decisive and firm implementation of that practice in what was to become the Health Sciences was that the area became an attractor for young researchers in the basic biological sciences, namely, molecular, cellular and developmental biology. Reciprocally, the entry of basic biological scientists into medically oriented groups totally changed the landscape, the soil, the seeding, the crossfertilization and the flowering of biomedical research in the country. This paper is a personal account of the experience of a scientist who was asked by the then President of the National Research Council, José Mariano Gago to co-ordinate the introduction of external evaluation of research projects and research institutes in the Health Sciences in Portugal between 1986 and 1997.
\end{abstract}

KEY WORDS: Portugal, evaluation, health sciences, CIÊNCIA Program, INSERM

Portugal is celebrating in 2006 its first 20 years of the formal introduction of the practice of external evaluation of research proposals in the national funding system. Accounts of changes in numbers of publications, citations, numbers of research projects funded and budget figures can be found in Government Reports (www.oces.mctes.pt). An offshoot of the decisive and firm implementation of that practice in what was to become the Health Sciences was that the area became an attractor for young researchers in the basic biological sciences, namely, molecular, cellular and developmental biology. This paper is a personal account of the experience of a scientist co-ordinating the development of research in the Health Sciences between 1986 and 1997. During those years I was responsible for co-ordinating external peer review panels composed of Portuguese scientists working abroad and foreign scientists with the shared and only goal of identifying the emerging Portuguese Biomedical Research. The job of the co-ordinator is not an executive job. His/her function is to listen, to transmit and to monitor the implementation of the recommendations made by the external panels to the Principal Investigator responsible for each proposal and to the President of the National Science Funding Agency (first JNICT, later FCT).
My unawareness of the political undertones of many events reflected by successive changes in the figure of Presidents and Vice-Presidents of the National Science Funding Agency has contributed for a continuity of action in the most fruitful company of actively participative members of the Committee that I was chairing. That same attitude led to my borrowing Weaver's statement in 1987 and for considering it still appropriate for the title of this paper (see Peel, 1986). The more stable pillars of continuity, however, resided in the people responsible for the day to day running of the Agency in staffing conditions that did not grow proportionally to the increase in budgets and numbers of projects funded.

My personal contribution and commitment to the development of the Biomedical Sciences in Portugal started in 1986 with an invitation of Mariano Gago, the then President of the National Science and Technology Organisation JNICT to become a member of his Advisory Board (Fig. 1). In accepting the invitation, I was to implement Mariano Gago's directives and become part of the introduction of the practice of external evaluation of research

Abbreviations used in this paper: FCT, Fundação para a Ciência e Tecnologia; JNICT, Junta Nacional para a Investigação Científica e Tecnológica.

\footnotetext{
*Address correspondence to: Prof. Maria de Sousa, Iron Genes and Immune System, IBMC, Rua do Campo Alegre 823, $4150-180$ Porto, Portugal. Tel: +351-22-607-4956. Fax: +351-22-609-8480. e-mail: mdesousa@ibmc.up.pt web: http://www.ibmc.org
} 

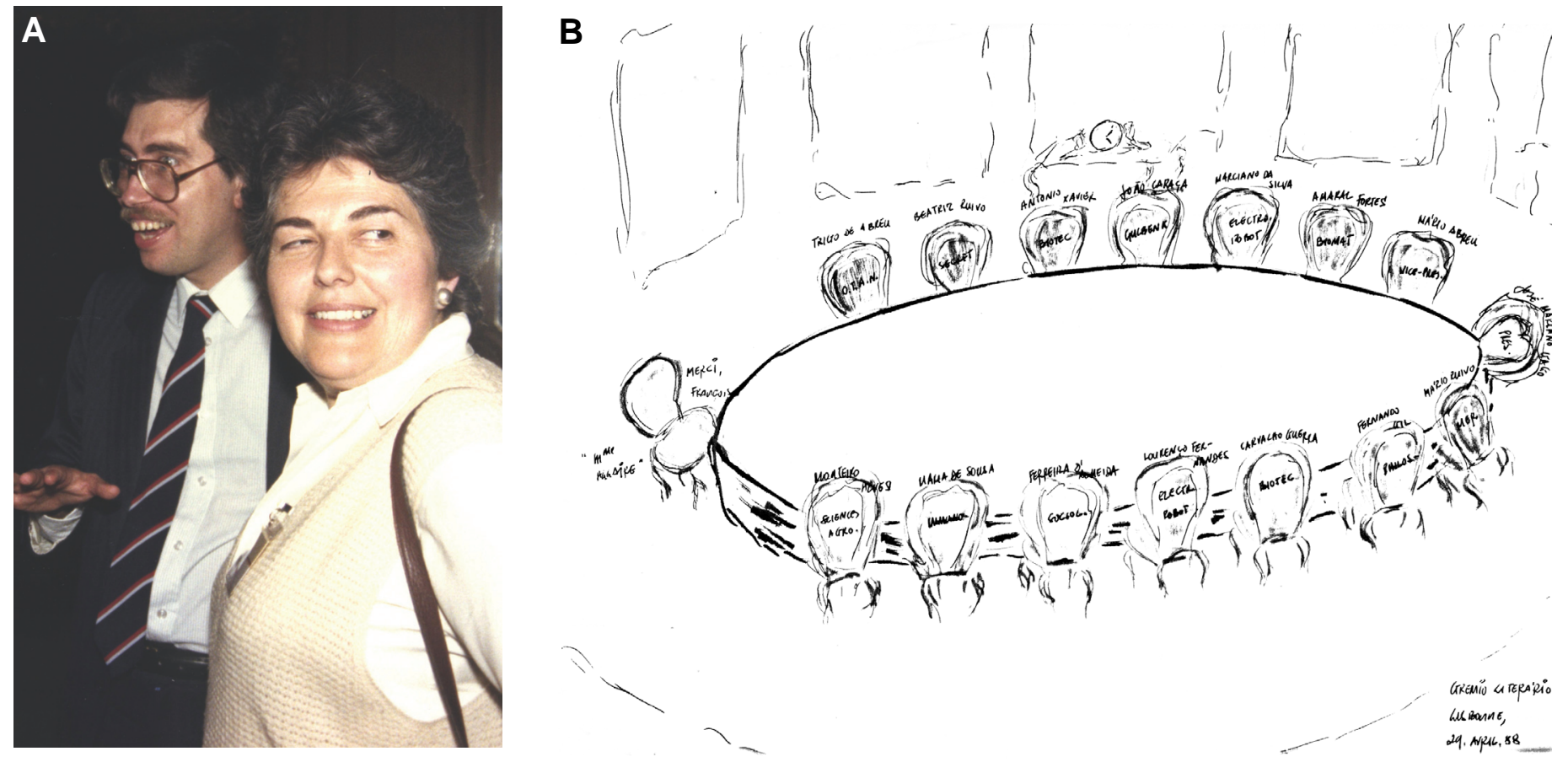

Fig. 1. Two images at the start of modern Biological Science in Portugal. (A) Maria de Sousa and José Mariano Gago at the 1987 Forum for Science and Technology and (B) the meeting of the Presidential Advisory Board of the "Junta Nacional para a Investigação Científica e Tecnológica" (JNICT) in April 1988 on the occasion of a tribute to Françoise Allaire for her work in Portugal as Science attaché at the French Embassy. The names of members of the Presidential Advisory Board can be seen on the backs of the chairs. From the left, clock-wise: Madame Allaire (merci, Françoise), Trigo de Abreu (NATO), Beatriz Ruivo (secretary), António Xavier (Biotechnology), João Caraça (representative from Fundação Calouste Gulbenkian), Marciano da Silva (Engineering and Robotics), Amaral Fortes (Biomaterials), Mário Abreu (Vice- president), José Mariano Gago (President), Mário Ruivo (Marine Sciences), Fernando Gil (Philosophy), Carvalho Guerra (Biotechnology), Lourenço Fernandes (Engineering and Robotics), Ferreira de Almeida (Social Sciences), Maria de Sousa (Health Sciences) and Monteiro Alves (Agricultural Sciences). Drawing by the author.

proposals in Portugal. To organize the evaluation of proposals I had to mobilize several colleagues from different countries. Some of these scientists became themselves an integral part of the process and a few continue to work with FCT.

A certain sense of happiness grew in 1987 with the realization that first, several groups working in Portugal «survived» a strict Science Citation Index (SCI) analysis and second, that young investigators trained in cellular, molecular and developmental biology abroad were returning to Portugal. The «offerings» of the so-called CIENCIA Program in 1991 were going to permit the return and settling of yet more outstanding younger people.

This paper is written in a half-objective, half-subjective manner in honour of a scientific community that imposed itself in extraordinary scarce funding conditions, inconceivable today. Biological Research had not been singled out or even identified as a priority program in the late $80 \mathrm{~s}$. The Biological Sciences exist today as a prominent research area in Portugal not because some committee more politically than scientifically inclined thought of it as a good thing to get funds from Brussels. Rather, it affirmed itself because it had competent scientists that were to impose themselves as the result of peer review criteria. Portuguese biological research had also some history with contributions that time permitted to judge as significant, made before 1970. However, with few exceptions, most of those contributions were accomplished by Portuguese researchers working in laboratories abroad (see for example, Lima de Faria, 1959; Parrott et al., 1966; Cunha-Vaz and Maurice, 1967; Lopes da Silva and Kamp, 1969; Pinto da Silva and Branton, 1970;Gronowicz et al., 1976;
Damasio and Maurer, 1978).

In 1985 I myself had started to work in Portugal after 20 years in the UK and the USA. I knew very little about European biomedical research systems outside the UK and virtually nothing about Science or scientists working in Portugal at the time. Both in the process of learning about Science in Portugal and later in implementing evaluation of proposals for research institutes I was much helped by two "French Connections". First help came from the extensive knowledge of the Portuguese scientific community of the Science attaché to the French Embassy in the late eighties, Madame Françoise Allaire. At the request of the French Embassy in Lisbon, an INSERM mission had expressed in 1986 the possibility of co-operation with Portugal. Later the joint participation of INSERM scientists in the evaluation of proposals to the CIENCIA Program proved invaluable. It reflected in part the large and generous vision of Philippe Lazar, the then President of INSERM and the commitment to the achievement of international partnerships of the International Relations division of INSERM directed at the time by Christine Chirol and applied on the ground by Guy Renaud. The valuable work of Françoise Allaire in Portugal was to be formally acknowledged by Mariano Gago and his Advisory Board in a discreet tribute in April 1988 on her departure from the Embassy (Fig. 1).

\section{Introducing scientific peer review in Portugal}

Of these wishes that they had forward they well knew that none could be obtained. They deliberated awhile what was to 
be done and resolved, when the inundation should cease, to return to Abyssinia. (Johnson, 1759)

Countries, like people, have a place and a date of birth. Unlike people, however, countries cannot decide the shaping of their future by moving from one place to another. While Rasselas, Prince of Abyssinia traveled with Imlac, Abyissinia did not move (Johnson, 1975). A country will stay in the same place until it may transform itself into something else but never into "somewhere» else. Presently, Portugal is a country whose root for fame lies in its contribution to the discoveries in the XV and XVI centuries. Such a root is also the cause of its virtual absence from the birth of experimental science and the so-called Golden Age that was to transform the world at the end of the XVII century. To miss that period had a price, not just in the nature of learning and the nature of knowing in the centuries that followed but, above all, in the shaping of attitudes towards questioning and doubting. The harvest of a country not sown by the seeds of doubt, questioning without fear and proof seeking, is of necessity, a harvest of dogmas. In the particular case of countries where the power of the Inquisition dominated, the dogmas were inevitably religious (reviewed in De Sousa, 2002). The unique mixture of earlier success in parting and the penalty for rebelling (to the extent of being tortured and burnt at the stake), signified that those Portuguese who felt the least at ease «at home» left Portugal in earlier centuries.

In the early sixties of the XX century, parting took many scientifically qualified young rebels to other European countries and to the U.SA. Portugal, under the dictatorship of Oliveira Salazar started a war with the African liberation movements to keep its African colonies, a war that would end only with the revolution of April 1974. The revolution liberated the country from the fear of questioning and doubting, but transiently it gave such power to questioning that many other matters became much more important than finding answers to scientific questions. In my view, biological and biomedical research in a modern sense, as a collective endeavour, only starts in Portugal in the last 20 years of the $X X$ century with the Science Mobilizing Program initiated by Mariano Gago. This does not exclude the pioneering contributions of remarkable men like Egas Moniz, A. Celestino da Costa,

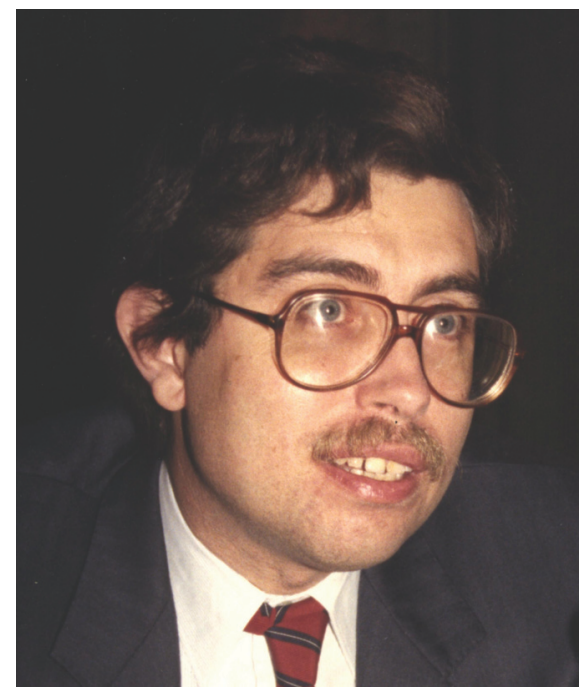

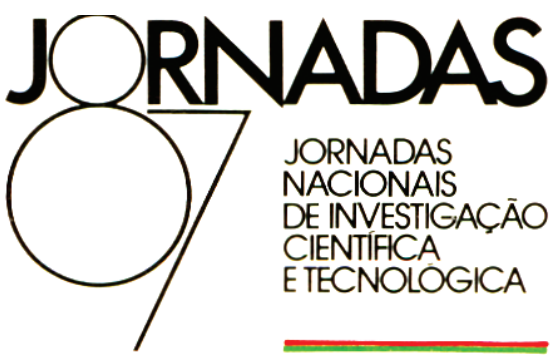

Fig. 2. "The prince desired to see all parts of government with his own eyes". José Mariano Gago launched a Forum for Science and Technology which took place in Lisbon in May 1987 and had its own attractive logo.
Aurélio Quintanilha, Corino de Andrade and many others working in Portugal in the first half of the XX century. Pioneers, however, are only pioneers if their thought, work and courage, are acknowledged later, by those who collectively will build something larger, more visible, perhaps less courageous but giving the necessary substance and continuity to the pioneering.

\section{The 1987 Forum for Science and Technology}

The prince desired a little kingdom, in which he might administer justice in his own person and see all parts of government with his own eyes.. (Johnson, 1759)

The Mobilizing Program was launched with a forum for Science and Technology organized in Lisbon in May 1987 with an eyecatching logo (Fig. 2). Representatives of all walks of scientific life from within and without the country came to that forum as perhaps the most vivid expression of the Mobilizing power of Mariano Gago himself and of his wish of seeing "all parts of government with his own eyes".

At this forum, I raised three fundamental questions. The first question was on which stage was the action going to be set? To define the stage I resorted to an essay by Yehuda Elkana looking at Science in the perspectives of Greek and Epic theatre. In Greek drama, the action develops as inevitable "fate is immutable and man can influence only in minor detail the when and where of his own destiny.» In contrast, epic theatre questions "Why did it happen the way it did? It could have happened otherwise..". As Elkana points out "There is nothing inevitable in the uniqueness of Western Science." My answer to the first question was therefore: "On a stage where lessons can be drawn from history, where the action is not inevitable and can be influenced differently by the different sets of decisions we may reach today."

My second question, within which context should it develop? In 1987, there seemed «little point in allotting money for research institutes, research equipment, or research grants, before discussing the context within which decisions for such allotments were being made. For if the context within which a decision is made is not defined and discussed, decision making in the long run will be determined by the fate of centrifuges and the fate of books and it is inevitable that centrifuges will break down and books will soon become out of date; having decided that action would develop on an epic stage, it could not be prompted by the immutable fate of objects." Two contexts were also considered for the development of scientific knowledge: a context of justification and a context of discovery. In a context of justification, the importance of any scientific activity resides in its finished product. In a context of discovery, because what one sees is already influenced by the expectation in the formulation of the questions, theory and practice become inseparable. 
Finally, which praxis was to be adopted? What were we to do as a community I asked, to signal our readiness to work in a context of justification and argue the case for being allowed room to work in the context of discovery. In the context of justification, I argued that scientists must relate to the reality of the country within which they live. Portugal could in 1987 distinguish itself from countries as near as Spain or France, by its past and present connections with Africa; by its comparatively stable rural population open to the persistence of genetic diseases and parasitic, viral and microbial infections. In the context of discovery a country should relate to the scientists it has. The scientists' proposition was their track record and their willingness to have their proposals evaluated by the international community. According to all views expressed, the key to improvement of a small scientific community depended on the analysis of the track record of its members, by internationally accepted methods. These should include scientific productivity, number and quality of publications, number of citations of papers published, etc. and the willingness to be the object of external peer review.

\section{The first external peer reviewing: 1986/87}

External peer reviewing of research projects was first implemented in the evaluation of the proposals submitted to the JNICT in 1986. Submission of written proposals was followed by the public presentation of research projects in scientific sessions chaired by me and the visiting scientist-evaluators. This meant that it was possible to identify clearly those groups whose scientific productivity and full time research commitment were likely to have a significant impact in the development of the Biomedical Sciences in the country and an impact on the projection of Portugal's reputation outside the country. We always tried to mix as referees non Portuguese speaking scientists with Portuguese researchers working abroad. All presentations were expected to be in English. Only one or two recalcitrant investigators protested against the presentation in English. In general, however, the co-operation of all for the success of the public presentation sessions was quite remarkable.

\section{The CIENCIA Program: 1991}

The combined implementation of this evaluation method led to recognition by the panels that one of the most serious problems with the Portuguese Scientific Community was its lack of density as well as critical mass. The European-funded CIENCIA Program was therefore targeted for three principal measures: 1) Creating an Innovation agency;2) Building new structures and updating of equipment; and 3) Creation of training opportunities through a program of MSc and PhD Fellowships. The Program had also as one of its main political objectives to correct regional differences in the country. As stated in the hand written text shown in Fig. 3, I felt that the principal objective of a Science program should be the Science and the opinion of the ablest scientists that were to be involved. External evaluation of proposals for new
Institutes and Centers was therefore done also by external peer reviewing. This time, however, not on an individual basis but institutionally, through INSERM. The INSERM members of the panel met first in Paris with the members of a Portuguese committee for evaluation of pre-proposals. Later they visited the labs invited to submit proposals. After the site-visit, the INSERM panel chaired by Arnold Munnich highlighted that "a major weakness identified derives from resistance of individual scientists to work in structured larger teams". Later, in 1994, another panel of external Advisors manifested apprehension "concerning the recognition of dispersion of resources and the continued existence of "walls" between groups".

\section{The first evaluation of research Units: 1996}

In 1996 Mariano Gago, then Minister for Science and Technology, requested an evaluation of the Research Units that had been receiving support since 1994. The Review Committee included some members of previous panels (M. Zalutsky from Duke University, J. Monjardino from St. Mary's Medical School, London and F. Lopes da Silva, from Amsterdam University), several new individual members from Cambridge, Barcelona, Bonn, Stockholm and London and supporting technical staff from JNICT (Figs. 4 and 5). Additional members invited on an institutional basis came from the INSERM and the Swedish Pharmaceutical Company Astra.

The evaluation process involved analysis of the written reports,

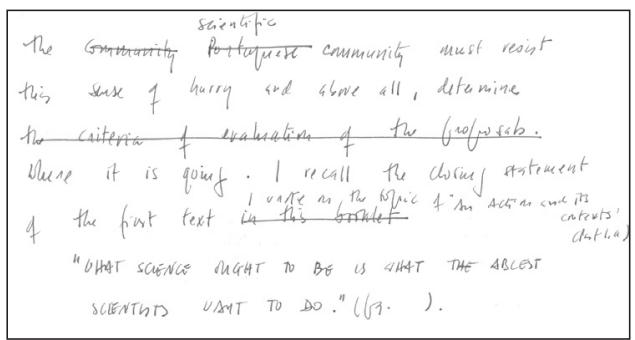

The scientific community must resist this
sense of hurry and above all, determine
where it is going. I recall the closing
statement of the first text I wrote on the topic
of "An action and its contexts" (Part 1.a).
WHAT SCIENCE OUGHT TO BE IS
WHAT THE ABLEST SCIENTISTS
WANT TO DO." (1)

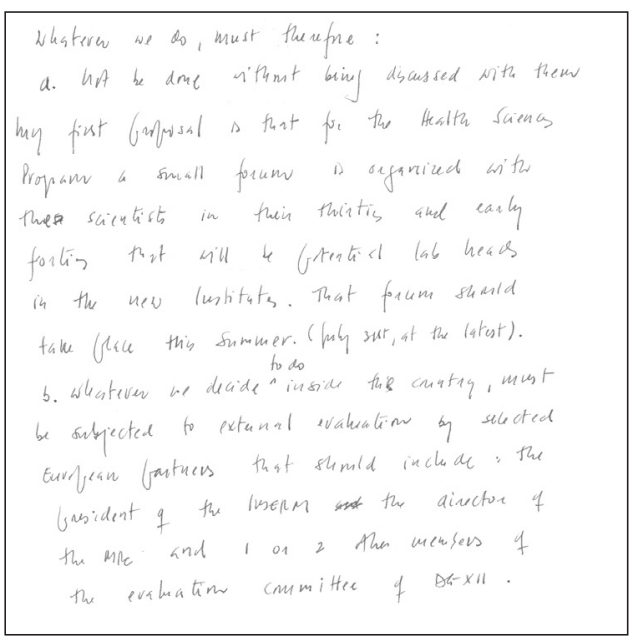

Whatever we do, must therefore:

a. Not be done without being discussed with them my first proposal is that for the Health Sciences Program a small forum is organized with the scientists in their thirties and early forties that will be potential lab heads in the new institutes. That forum should take place this summer (July $31^{\text {st }}$, at the latest).

b. Whatever we decide to do inside this country, must be subjected to external evaluation by selected European partners that should include: the president of the INSERM, the director of the MRC and 1 or 2 of the members of the evaluation committee of DG XII.

Fig. 3. "What Science ought to be is what the ablest scientists really want to do" (in Peel, 1986). Hand written notes by the author referring to implementation of the CIENCIA Program, 1991. 


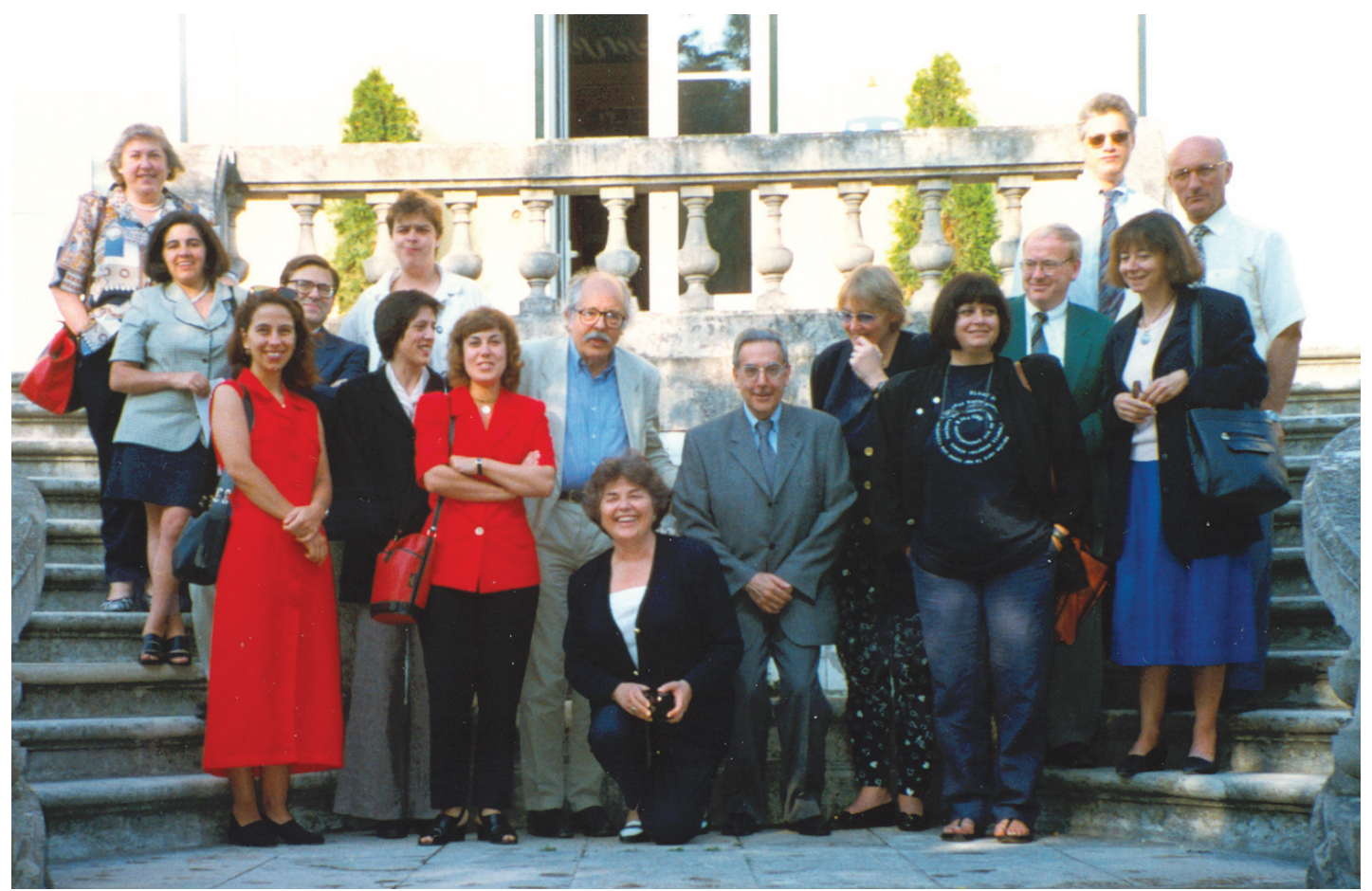

Fig. 4. Site visit to Research Units in 1997. Group picture of scientific members of the Review Committee and technical staff from JNICT taken in Coimbra during the site visit to research units in Lisbon, Coimbra and Porto. From left to right, Deolinda Ferreira (JNICT), Ana Fonseca (JNICT), Paula Almeida (JNICT), Fernando Lopes da Silva (University of Amsterdam), Helen Borrens (JNICT), Paula Trindade (JNICT), Rosário Conceição (JNICT), João Monjardino (Imperial College, London), Maria de Sousa (Porto University, Chair), Fernando Tomé (INSERM, Paris), Rosie Eloy (INSERM,Biomatec,Lyon), Benedita Rocha (INSERM, Paris), Magnus Nordenskjold (Karolinska Institute, Sweden), Mihael Zalutsky (Duke University, USA), Teresa Patrício (observer), Guy Renauld (International Relations, INSERM).

site visits and final discussion by panel members. In all, 20 Units were site visited distributed in Lisboa, Coimbra and Porto. The Units visited were classified according to the following criteria: scientific productivity and impact, integration, intellectual vision and the ability to foster integration, unit viability in the face of the nature of Portuguese bureaucracy, capacity to raise external funding, capacity to develop international cooperation, capacity to attract and employ younger scientists trained abroad. The impact of re-entry of some of these younger scientists in the fabric of research and research institutes in the Biological Sciences started to be reflected in the number of publications and citations in Biomedical Research and more specifically in Molecular Biology and Genetics (Fig. 6).

In general, panel members felt that scientists were spending too much time to insure basic survival of the physical environment in which they work. Raising funds to cover operating costs for the new buildings was detracting significantly from the ability to afford to do research. It was also found that in most cases senior personnel did not appear to meet regularly to coordinate efforts both practical (equipment sharing, personnel appointments, etc) and intellectual (defining and following up implementation of research directions). Panel members also expressed concern over the future of younger scientists, highlighting the lack of an appropriate track at Universities (particularly in medical schools) that permits to pursue an academic research career.

The panel provided a number of recommendations ranging from guidelines on how to prepare future written progress reports and organization of the site visits to the role of the international scientific advisory boards. Furthermore, a number of novel proposals were put forward. Namely, the concept of career development awards was proposed. This would lead to the selection for the next 4 years of approximately 10 highly promising young researchers with a secure funding commitment for 3-5 years with integration at the end of the 4 years in a host institution. These funds should not be tied to the school but to the individual. Other proposals included the attribution of short term retraining grants, where learning a new technique abroad is indispensable to set it up in the Portuguese lab, short term visiting grants, where the need to visit another lab inside or outside the country becomes urgent in the context of the current work of the Unit. Finally, it was felt that the Portuguese Scientific Community in the Biomedical

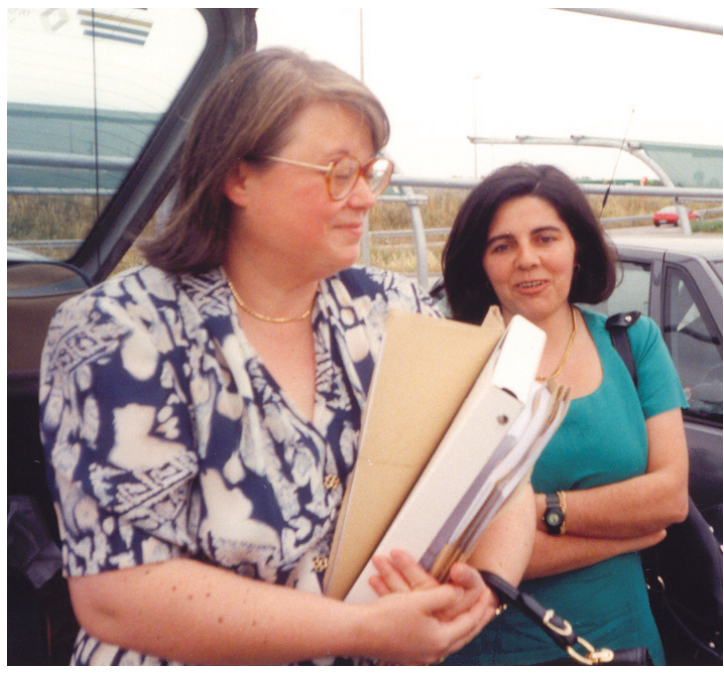

Fig. 5. Senior staff members from the National Research Council supporting the Review Committee during the site visit to Research Units in 1997. Olga Martinho (left) and Ana Fonseca (right) are presently responsible for running the FCT Fellowship and Projects Division, respectively. 
Sciences was, in general, of sufficient quality and covering areas of sufficient relevance to the Health, Research, Education and Development of the country, to be encouraged to take the step of organizing itself, like in the U.S. in order to effectively lobby for more funds. In addition, alternative mechanisms for funding (Charity, Industry) need to be given serious attention.

Importantly, a sense of dissatisfaction started to permeate the minds of some members of the evaluation panels, particularly those that were Portuguese scientists pursuing successful careers abroad. I myself expressed in a letter directed to the President of the National Science Funding Agency, my own principal concern thus: "Portugal is one of the few Southern European countries that started, since 1987 , the procedure of international peer review. If such a procedure becomes to the eye of the external peer reviewer a cosmetic and not a truly surgical exercise, that respect which took solong to build could vanish."

\section{Caveat: much of it will not work here if we are not careful}

Between 1990 and 2005 a total of 11,299 fellowships have been attributed to graduate students in all scientific areas to develop research projects either abroad or within Portugal, with a steady increase in the proportion of projects done largely in national laboratories. In 1986, the Agency funded 48 research grants with a budget of 425.000 Euros. Between 2000 and 2002, 294 research grants were funded with a budget of 22,794,761 Euros. In 2006, 698 grant applications have been received only in the Biomedical Sciences.

As I read through these numbers, I hesitate to rejoice without further warning. It is presumptuous to think that pieces of advice can work "instantly" in a country without history in modern science. As Medawar (1979) says on Creativity: "To be creative, scientists need libraries and laboratories and the company of other scientists. "There is a great deal of evidence that Portuguese scientists are highly creative. In the biological/biomedical sciences, a number of original contributions have been made by scientists born in this country.

\section{Biomedical Research}

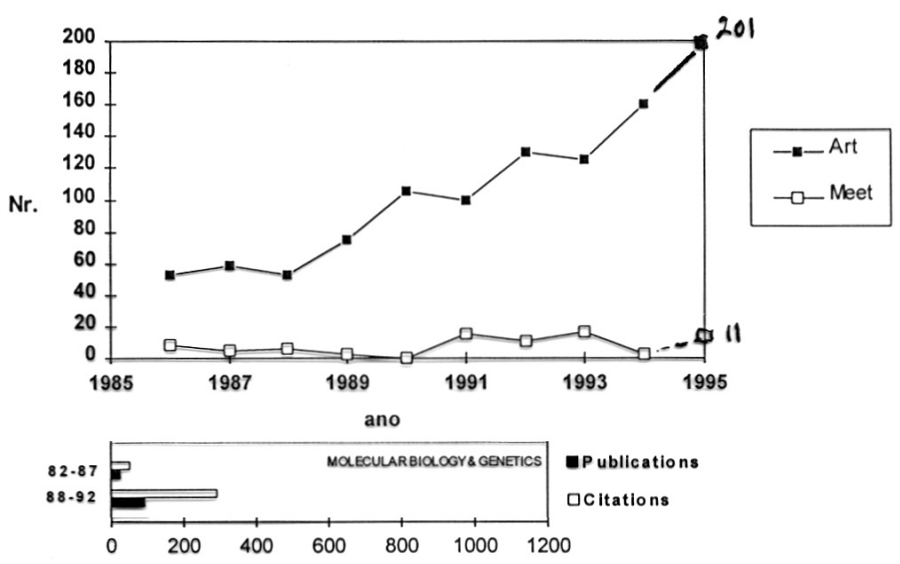

Fig. 6. Number of Portuguese publications in the Biomedical Sciences between 1986 and 1995. (Upper graph) Article represents peer reviewed publications; Meetings represents published contributions to international conferences. (Lower graph) Number of publications and citations in Molecular Biology and Genetics (source SCl, courtesy of C. Marciano da Silva).
Working in places where they had access to libraries that were open, laboratories with equipment that worked, reagents that arrived within 24 hours of being ordered and a company of scientists that talked to each other, welcomed the young and did not feel threatened by the more aggressive. None of the pieces of Advice extracted for this caveat seemed to have the same meaning in a country without a great national Science library, without firms that would secure the prompt repairing of equipment or delivery of reagents. None of it. All of it, however, seemed necessary because of the evidence that young and not so young Portuguese have made and continue to make successful scientific careers in the most competitive environments in the U.S. and Europe. All of it is necessary because, in the end, a scientific country is not microscopes, centrifuges and spectrophotometers, but men and women capable of using them and fighting for their maintenance. That is perhaps the first role of a Research Director in a developing country; that things work and that the established don't fear or feel threatened by the younger and the most daring. That, collectively, we behave at the dawn of the XXI century as our ancestors did, round Pasteur and Curie at the beginning of the $X X$ century, with greater effort. For there is no evidence of a Pasteur or a Curie working within Portugal. However, the tradition does not have to develop solely with one man or one woman, but with one collegial community, so successfully illustrated by the European Molecular Biology Laboratory (EMBL). That, the Portuguese conquered in the last 10 years.

\section{Concluding remarks}

I hope the content of the present paper contributes to the understanding of how research in the Biological Sciences developed in Portugal and how it decisively influenced the development of Biomedical Research during the last decade of the XX century. But for those who have the responsibility of governing a reminder must be left that success in scientific achievements cannot go unaccompanied by an equally strong and capable funding Agency with a human and technical infrastructure adequately staffed, in number and professional capability. The last word should, however, be the philosopher's:

"There is no part of history so generally useful as that which relates to the progress of the human mind, the gradual improvement of reason, the successive advances of science, the vicissitudes of learning and ignorance, which are the light and darkness of thinking beings, the extinction and resuscitation of arts and the revolutions of the intellectual world. If accounts of battles and invasions are peculiarly the business of princes, the useful or elegant arts are not to be neglected; those who have kingdoms to govern have understandings to cultivate". (Johnson, 1759)

\section{Acknowledgements}

I wish to acknowledge Ana Fonseca and Olga Martinho for help with materials consulted during the preparation of this paper, Gabriela Lopes da Silva and Manuela Ramos for the photos of the inaugural session of the 1987 Jornadas for Science and technology, Jorge Pinto for the preparation of the illustrations and Carmo Fonseca for the challenge.

\section{References}

CUNHA-VAZ, J. and MAURICE, D.M. (1967). The active transport of fluorescein by the retinal vessels and the retina. J Physiol. 191:467-86.

DAMASIO, A.R. and MAURER, RG (1978). Neurological model for childhood 
autism. Arch. Neurol. 35: 777-786.

DE SOUSA, M. (2002). Investigação Médica em Portugal: llustrações e lições. Medicina Interna, 9:6-11

GRONOWICZ, E, COUTINHO, A and MELCHERS, F. (1976) Plaque assay for all cells secreting Ig of a given type or class. Eur. J. Immunol. 6:588-590.

JOHNSON, S. (1759). The History of Rasselas Prince of Abyssinia. 1975 edition of the Folio Society London.

LIMA-DE-FARIA, A (1959). Differential uptake of tritiated thymidine into hetero-and euchromatin in Melanoplus and Secale. J. Biophys Biochem Cyto/6: 457-466.

LOPES DA SILVA, F.H. and KAMP, A. (1969). Hippocampal theta frequency shifts and operant behaviour. Electroencephalogr Clin Neurophysiol. 26:133-43.

MEDAWAR, P.B. (1979). Advice to a young scientist. Harper and Row, New York.

PARROTT, D.V., DE SOUSA, M.A., EAST, J. (1966). Thymus-dependent areas in the lymphoid organs of neonatally thymectomized mice. J Exp Med. 123:191204.

PEEL, G. (1986). The natural Philosophy of the Constitution. Science 233: 1056 1060.

PINTO DA SILVA, P. and BRANTON, D. (1970) Membrane splitting in freezeethching. Covalently bound ferritin as a membrane marker. J Cel/ Biol. 45:598 605.

\section{Further Related Reading, published previously in the Int. J. Dev. Biol.}

See our recent Special Issue Ear Development edited by Fernando Giraldez and Bernd Fritzsch at: http://www.ijdb.ehu.es/web/contents.php?vol=51\&issue=6-7

The road to the vertebral formula

Moisés Mallo, Tânia Vinagre and Marta Carapuço

Int. J. Dev. Biol. (2009) 53: 1469-1481

Raquel P. Andrade and Leonor Saúde

Int. J. Dev. Biol. (2007) 51: 177-182

$\mathrm{N}$-acetylgalactosamine 4-sulfate 6-0-sulfotransferase expression during early mouse embryonic development

Ana-Marisa Salgueiro, Mário Filipe and José-António Belo

Int. J. Dev. Biol. (2006) 50: 705-708

Developmental expression of Shisa-2 in Xenopus laevis

Ana-Cristina Silva, Mário Filipe, Marta Vitorino, Herbert Steinbeisser and José-António Belo Int. J. Dev. Biol. (2006) 50: 575-579

Head-tail patterning of the vertebrate embryo: one, two or many unresolved problems? Claudio D. Stern, Jeroen Charité, Jacqueline Deschamps, Denis Duboule, Anthony J. Durston, Marie Kmita, Jean-François Nicolas, Isabel Palmeirim, Jim C. Smith and Lewis Wolpert

Int. J. Dev. Biol. (2006) 50: 3-15

Running after the clock

Catarina Freitas, Sofia Rodrigues, Leonor Saúde and Isabel Palmeirim

Int. J. Dev. Biol. (2005) 49: 317-324

The making of gametes in higher plants

Leonor C. Boavida, Jörg D. Becker and José A. Feijó

Int. J. Dev. Biol. (2005) 49: 595-614

Gametophyte interaction and sexual reproduction: how plants make a zygote Leonor C. Boavida, Ana Maria Vieira, Jörg D. Becker and José A. Feijó Int. J. Dev. Biol. (2005) 49: 615-632

The Le Douarin phenomenon: a shift in the paradigm of developmental self-tolerance António Coutinho Int. J. Dev. Biol. (2005) 49: 131-136

EST analysis of mRNAs expressed during embryogenesis in Gallus gallus Erika C. Jorge, Claudia B. Monteiro-Vitorello, Helena J. Alves, Clarissa S. Silva, Rachel G. Balan, Mateus Patrício and Luiz L. Coutinho Int. J. Dev. Biol. (2004) 48: 333-337

Goosecoid and cerberus-like do not interact during mouse embryogenesis. Ana C Borges, Sara Marques and José A Belo Int. J. Dev. Biol. (2002) 46: 259-262

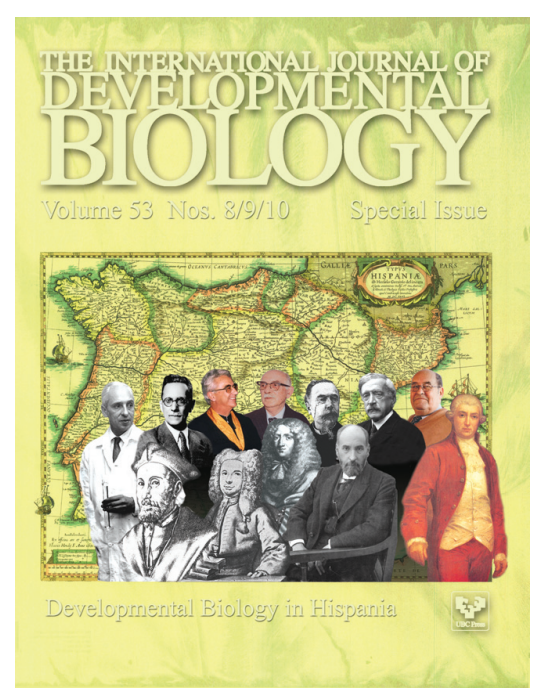

5 yr ISI Impact Factor $(2008)=3.271$

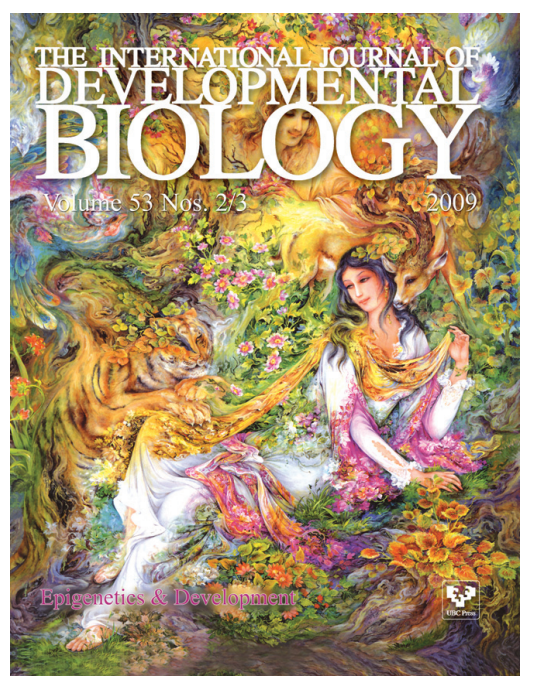

